\title{
ALGORITMA K-MEDOIDS UNTUK CLUSTERING PENYAKIT MAAG DI KABUPATEN KARAWANG
}

\author{
Siti Nurlaela ${ }^{1}$, Aji Primajaya ${ }^{2}$, Tesa Nur Padilah ${ }^{3}$ \\ ${ }^{1,2,3}$ Universitas Singaperbangsa Karawang \\ Jl. H.S. Ronggowaluyo, Teluk Jambe Timur, Karawang, 41361 1,2,3 \\ e-mail : Siti.16210@ student.unsika.ac.id ${ }^{1}$, aji.primajaya@ staff.unsika.ac.id ${ }^{2}$ \\ tesa.nurpadilah@staff.unsika.ac.id ${ }^{3}$
}

\begin{abstract}
ABSTRAK
Di Indonesia, persentase dari angka kejadian gastritis atau maag dari tahun 2017 sampai 2019, kasus penyakit maag mengalami kenaikan. Penyakit maag yang diderita oleh masyarakat Kabupaten Karawang tahun 2019 yaitu sebanyak 75.343 kasus, dengan jumlah penduduk sebanyak 2.353.915 jiwa. Salah satu cara untuk membantu Dinas Kesehatan Kabupaten Karawang dalam prioritas penanganan penyakit maag ialah dengan mencari daerah dengan tingkat penyakit maag tertinggi di Karawang. Untuk mengetahui prioritas daerah tingkat penyakit maag tertinggi di Kabupaten Karawang yang perlu ditangani maka dapat menggunakan teknik data mining dan metode yang digunakan yaitu clustering. Algoritma clustering yang digunakan dalam penelitian ini yaitu algoritma K-Medoids dengan pengukuran Euclidean Distance. hasil yang didapatkan pada dataset Penyakit Maag Kabupaten Karawang Tahun 2017-2019 memiliki cluster optimal sebanyak 2 cluster, dimana cluster 1 dengan 35 daerah dan dikategorikan rendah, dan pada cluster 2 dengan 15 daerah yang dikategorikan tinggi, dan menghasilkan nilai Silhouette Coefficient sebesar 0,5561
\end{abstract}

Kata kunci : Gastritis, K-Medoids, Silhouette Coefficient

\begin{abstract}
In Indonesia, the percentage of the incidence of gastritis or gastritis from 2017 to 2019, cases of ulcer disease have increased. Ulcer disease suffered by the people of Karawang Regency in 2019 amounted to 75,343 cases, with a population of 2,353,915 people. One of the ways to help the Karawang Regency Health Office in the priority of handling ulcer disease is to find areas with the highest rates of ulcer disease in Karawang. To find out the priority areas of the highest level of ulcer disease in Karawang Regency that need to be addressed, data mining techniques can be used and the method used is clustering. The clustering algorithm used in this study is the K-Medoids algorithm with Euclidean Distance measurement. The results obtained in the dataset for ulcer disease in Karawang Regency in 2017-2019 have an optimal cluster of 2 clusters, where cluster 1 is categorized as low, and cluster 2 with 15 areas that are categorized as high, and produces a Silhouette Coefficient value of 0.5561.
\end{abstract}

Keywords : Gastritis, K-Medoids, Silhouette Coefficient

\section{PENDAHULUAN}

Gastritis atau biasa disebut dengan penyakit maag merupakan proses inflamasi atau gangguan kesehatan yang disebabkan oleh faktor iritasi dan infeksi pada mukosa dan submukosa lambung (Tussakinah, Masrul, \& Burhan, 2018). Penyakit maag dapat menyerang semua kalangan masyarakat di usia produktif. Biasanya penyakit maag disebabkan oleh beberapa faktor seperti pola makan yang tidak teratur atau pola makan yang tidak baik dan faktor stress.

Menurut Profil Kesehatan Indonesia, persentase dari angka kejadian gastritis atau maag di Indonesia menurut WHO adalah 40,8\% dan angka kejadian penyakit maag di beberapa daerah di Indonesia cukup tinggi dengan angka kejadian 274.396 kasus dari 238.452.952 jiwa penduduk dan penyakit maag merupakan 10 
IN F ORMA TIK

Jurnal Informatika, Manajemen dan Komputer, Vol. 12 No. 2, Desember 2020

eISSN : 2580-3042

pISSN : 1979-0694

penyakit terbanyak pada pasien rawat inap di rumah sakit di Indonesia sebesar 30.154 kasus $(4,9 \%)$ (Novitasary \& Ismail, 2017).

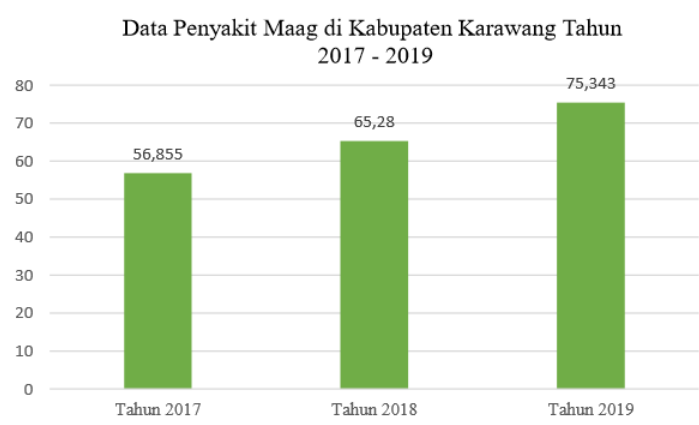

Gambar 1. Data Penyakit Maag di Kabupaten Karawang

Gambar 1 merupakan data penyakit maag yang ada di Kabupaten karawang. Dapat dilihat bahwa dari tahun 2017 sampai 2019, kasus penyakit maag mengalami kenaikan. Penyakit maag yang diderita oleh masyarakat Kabupaten Karawang tahun 2019 yaitu sebanyak 75.343 kasus, dengan jumlah penduduk sebanyak 2.353.915 jiwa (Statistik, 2019). Dengan demikian, jumlah penduduk dengan jumlah kasus penyakit memiliki perbandingan 1:31, artinya setiap 31 penduduk ada 1 kasus penyakit maag. Jika penyakit maag dibiarkan terus menerus maka akan merusak fungsi lambung dan dapat meningkatkan risiko untuk terkena kanker lambung hingga menyebabkan kematian. Salah satu cara untuk membantu Dinas Kesehatan Kabupaten Karawang dalam prioritas penanganan penyakit maag ialah dengan mencari daerah dengan tingkat penyakit maag tertinggi di Karawang. Hal ini dilakukan agar tindakan penanganan yang akan dilakukan dapat menjadi lebih efektif lagi dan berfokus pada daerah dengan penderita penyakit maag tertinggi di Karawang.

Untuk mengetahui prioritas daerah tingkat penyakit maag tertinggi di Kabupaten Karawang yang perlu ditangani maka dapat menggunakan teknik data mining. Data mining merupakan suatu metode yang digunakan dalam pengolahan data untuk menemukan pola yang tersembunyi dari data sehingga dapat menghasilkan pengetahuan (Wardhani \& Khrisna, 2016).

Data mining memiliki beberapa metode diantaranya asosiasi, deskripsi, estimasi, klasifikasi, clustering, dan prediksi. Dari beberapa metode data mining, salah satu metode yang akan diterapkan pada penelitian ini yaitu clustering. Clustering merupakan suatu proses pengelompokan dari kumpulan data menjadi beberapa kelompok sehingga objek yang terdapat pada satu kelompok mempunyai banyak kesamaan serta memiliki banyak perbedaan dengan kelompok lainnya (Rahmayani, 2018). Beberapa algoritma clustering yang dapat digunakan yaitu algoritma $K$-Medoids, K-Means, dan Fuzzy C-Means.

Pada penelitian (Marlina, Fernando, \& Ramadhan, 2018), tentang perbandingkan algoritma $K$-Medoids dan algoritma K-Means dapat disimpulkan bahwa algoritma $K$-Medoids menghasilkan nilai validitas lebih baik dalam pengelompokan pada data sebaran anak cacat jika dibandingkan dengan algoritma K-Means. Algoritma K-Medoids memiliki kelebihan mengatasi kelemahan yang ada di algoritma $K$ Means yang sensitive terhadap noise dan outlier (Riyanto, 2019). Algoritma K-Medoids lebih baik dibandingkan dengan K-Means karena $K$ Medoids merupakan salah satu metode clustering yang efisien untuk menangani dataset yang kecil (Rofiqi, 2017).

Algoritma $\mathrm{K}$-Medoids merupakan salah satu metode partisi clustering untuk mengelompokkan kumpulan $\mathrm{n}$ objek menjadi sejumlah $\mathrm{k}$ cluster (Rizby, 2018). Algoritma K-Medoids menggunakan objek pada kumpulan objek yang untuk mewakili sebuah cluster. Objek yang telah terpilih untuk mewakili sebuah cluster disebut dengan medoid. Algoritma K-Medoids bertujuan untuk mengurangi sensitivitas dari partisi yang dihasilkan sehubungan dengan nilai-nilai ekstrim yang ada didalam dataset, penggunaan medoids tidak berdasarkan dari pengamatan mean yang dimiliki oleh setiap cluster (Kamila, Khairunnisa, \& Mustakim, 2019).

Dari permasalahan di atas akan dilakukan penelitian yang bertujuan untuk mengetahui daerah dengan tingkat kasus penyakit maag yang rendah dan tinggi.

\section{a. Algoritma K-Medoids}

Algoritma K-Medoids atau Partitioning Around Medoids (PAM) merupakan suatu metode partisi clustering untuk mengelompokkan sekumpulan (n) objek menjadi sejumlah (k) cluster. Algoritma K-Medoids menggunakan objek pada kumpulan objek untuk mewakili sebuah cluster. Objek yang terpilih untuk mewakili sebuah cluster disebut medoid (Listiyanti, Syahbana, \& Henim, 2016).

Menurut Hardiyanti, Tambunan, \& Saragih (2019), berikut merupakan langkah- 
IN F O R M A I I A

Jurnal Informatika, Manajemen dan Komputer, Vol. 12 No. 2, Desember 2020

eISSN : 2580-3042

pISSN : 1979-0694

langkah dalam perhitungan algoritma $\mathrm{K}$-Medoids diantaranya :

1. Inisialisasikan pusat cluster sebanyak jumlah cluster (k).

2. Alokasikan setiap data (objek) ke cluster terdekat menggunakan persamaan ukuran jarak Euclidian Distance dengan persamaan:

$d\left(x_{i j}, c_{k j}\right)=\sqrt{\sum_{j=i}^{p} \sum_{i-1}^{n}\left(x_{i j}-c_{k j}\right)^{2}}$

Dimana:

$d\left(x_{i j}, c_{k j}\right)=$ Jarak Euclidian Distance antara pengamatan ke-i variabel ke-j ke pusat cluster ke-k pada variabel ke$\mathrm{j}$,

$x_{i j}=$ objek pada pengamatan ke-i pada variabel ke-j,

$c_{k j}=$ pusat kelompok ke-k pada variabel ke-j,

$p=$ banyaknya variabel yang diamati,

$n=$ banyak pengamatan yang diamati.

3. Pilih secara acak objek pada masing-masing cluster sebagai kandidat medoid baru.

4. Hitung jarak setiap objek yang berada pada masing-masing cluster dengan kandidat medoids baru.

5. Hitung total simpangan $(S)$ dengan menghitung nilai total distance baru - total distance lama. Jika $S<0$, maka tukar objek dengan data cluster untuk membentuk sekumpulan $k$ objek baru sebagai medoid.

6. Ulangi langkah 3 sampai 5 hingga tidak terjadi perubahan medoids, sehingga didapatkan cluster beserta anggota masingmasing cluster.

\section{b. Elbow Method}

Elbow Method merupakan salah satu dari metode yang digunakan untuk mendapatkan informasi dalam penentuan jumlah dalam suatu cluster terbaik dengan cara melihat hasil perbandingan dari presentase antar jumlah cluster yang membentuk siku pada suatu titik (Merliana \& Santoso, 2015). Adapun algoritma metode Elbow dalam menentukan nilai k pada $K$-Means adalah (Savitri, Bachtiar, \& Setiawan, 2009).

1. Inisialisasi $\mathrm{k}$

2. Mulai

3. kenaikan nilai $\mathrm{k}$

4. Mengukur SSE

$S S E=\sum_{K=1}^{K} \sum_{K_{i} \in S_{k}}\left\|X_{i}-C_{k}\right\|_{2}^{2}$

5. Jika di suatu titik SSE turun drastis

6. Hal tersebut menujukan nilai $\mathrm{k}$ yang benar

7. Selesai.

\section{c. Silhouette Coefficient}

Silhouette Coefficient merupakan sebuah metode evaluasi cluster yang bertujuan untuk melihat kualitas objek dalam suatu cluster. Adapun tahapan perhitungan Silhouette Coefficient menurut (Wira, Budianto, \& Wiguna, 2019) diantaranya :

1. Hitung jarak rata-rata dari suatu objek ke- $i$ dengan semua objek lain yang berada dalam satu cluster.

$a(i)=\frac{1}{[A]-1} \sum j \in_{A, j \neq i} d(i, j)$

2. Hitung rata-rata dari objek ke- $i$ tersebut dengan semua objek pada cluster yang lainnya, dan ambil nilai terkecilnya.

$$
d(i)=\frac{1}{[A]} \sum j \in C d(i, j)
$$

3. Nilai Silhouette Coefficient nya adalah:

Jumlah $s(i)$ diperoleh dengan menggabungkan $a(i)$ dan $b(i)$ :

$s= \begin{cases}1-\frac{a(i)}{b(i)}, & \text { if } a(i)<b(i) \\ 0 & \text { if } a(i)=b(i) \\ \frac{b(i)}{a(i)}-1, & \text { if } a(i)>b(i)\end{cases}$

Sehingga dapat dirumuskan:

$$
s(i)=\frac{b(i)-a(i)}{\max (a(i), b(i))}
$$

Dimana:

$s(i)=$ Nilai Silhouette.

$a(i)=$ Rata - rata jarak antara $i$ dengan semua objek pada cluster-nya.

$b(i)=$ Rata - rata jarak antara data $i$ pada semua objek pada cluster lain.

$d(i, j)=$ Jarak antara objek $i$ dengan $j$.

Nilai hasil dari metode silhouette coefficient berada berkisar antara -1 sampai dengan 1 . Adapun kriteria pengukuran nilai validasi metode silhouette coefficient dapat dilihat pada Tabel 1 (Wira et al., 2019). 
INFORMA TIK

Jurnal Informatika, Manajemen dan Komputer, Vol. 12 No. 2, Desember 2020

eISSN : 2580-3042

pISSN : 1979-0694

Tabel 1. Interpretasi Silhouette Coefficient

\begin{tabular}{|c|c|}
\hline $\begin{array}{c}\text { silhouette } \\
\text { coefficient }\end{array}$ & $\begin{array}{c}\text { Interpretasi yang } \\
\text { diusulkan }\end{array}$ \\
\hline $0.7<\mathrm{SC} \leq 1.0$ & Strong Sturucture \\
\hline $0,5<\mathrm{SC} \leq 0.7$ & Medium Sturucture \\
\hline $0.25<\mathrm{SC} \leq 0.5$ & Weak Sturucture \\
\hline $\mathrm{SC} \leq 0.25$ & No Sturucture \\
\hline
\end{tabular}

\section{METODOLOGI PENELITIAN}

Gambar 2 merupakan metodologi dari penelitian ini.

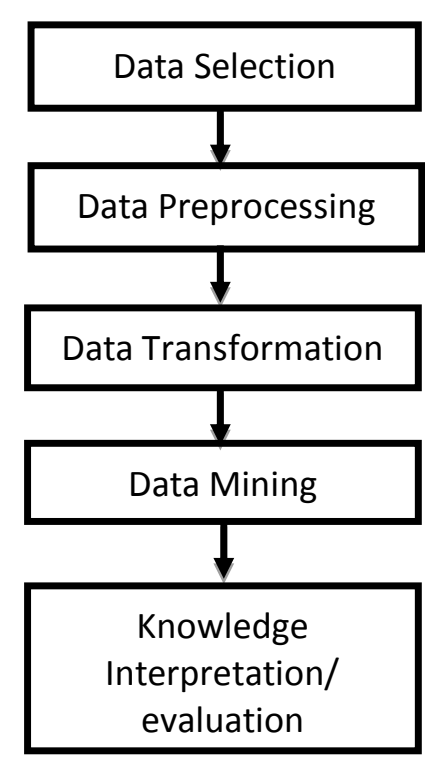

Gambar 2. Metodologi Penelitian

\section{a. Data Selection}

Pada tahap ini dilakukan pemilihan data. Data yang digunakan yaitu data penyakit maag Kabupaten Karawang tahun 2017-2019.

b. Data Preprocessing

Dalam tahap ini dilakukan proses pembersihan pada data antara lain membuang duplikasi data, memeriksa data inkonsisten, missing value, dan memperbaiki kesalahan pada data. Penanganna missing value akan dilakukan dengan imputasi data.

\section{c. Data Transformation}

Data transformation dilalukan untuk menyeragamkan data antara 0 dan 1 agar terhindar dari outlier.

\section{d. Data mining}

Pada tahap ini dilakukan proses data mining dengan algoritma K-Medoids. Namun sebelum itu dilakukan Elbow Method untuk menentukan jumlah cluster

\section{e. Knowledge Interpretation/Evaluation}

Tahap ini merupakan hasil dari data mining yang diinterpretasikan ke dalam gambar atau tabel serta dievaluasi dengan Silhouette Coefficient untuk melihat kualitas atau keakuratan dari cluster.

\section{HASIL DAN PEMBAHASAN \\ a. Data Selection}

Dataset yang digunakan dalam penelitian ini menggunakan dataset penyakit maag Kabupaten Karawang tahun 2017-2019 sebanyak 50 data dan 3 variabel. Dataset diperoleh dari Dinas Kesehatan Kabupaten Karawang.

Tabel 2 merupakan tabel hasil dari data selection pada dataset penyakit maag Kabupaten Karawang tahun 2017-2019.

Tabel 2. Contoh Dataset

\begin{tabular}{|c|c|c|}
\hline Puskesmas & $\begin{array}{c}\text { Jumlah } \\
\text { Penduduk }\end{array}$ & $\begin{array}{c}\text { Maag } \\
\text { Tahun 2017- } \\
\mathbf{2 0 1 9}\end{array}$ \\
\hline Pangkalan & 36.709 & - \\
\hline Loji & 40.609 & 2.299 \\
\hline Ciampel & 38.638 & 1.006 \\
\hline Telukjambe & 60.176 & - \\
\hline Wadas & 48.555 & 2.725 \\
\hline$\ldots$ & $\ldots$ & $\ldots$ \\
\hline Pakisjaya & 41.737 & 3.477 \\
\hline
\end{tabular}

\section{b. Data Preprocessing}

Setelah dilakukan data selection atau pemilihan data kemudian dilakukan penanganan missing value, duplikasi data dan data yang tidak sesuai atau inkonsisten data. Pada dataset penyakit maag Kabupaten Karawang tahun 20172019 yang digunakan terdapat beberapa data yang hilang atau missing value sehingga perlu dilakukan data pre-processing dengan menggunakan imputasi missing data dengan median. Tabel 3 merupakan hasil dari imputasi missing data.

Tabel 3. Dataset setelelah imputasi missing value

\begin{tabular}{|c|c|c|}
\hline Puskesmas & $\begin{array}{c}\text { Jumlah } \\
\text { Penduduk }\end{array}$ & $\begin{array}{c}\text { Maag } \\
\text { Tahun 2017- } \\
\text { 2019 }\end{array}$ \\
\hline Pangkalan & 36.709 & 2.725 \\
\hline Loji & 40.609 & 2.299 \\
\hline Ciampel & 38.638 & 1.006 \\
\hline Telukjambe & 60.176 & 2.725 \\
\hline
\end{tabular}


IN F ORMA T I K A

Jurnal Informatika, Manajemen dan Komputer, Vol. 12 No. 2, Desember 2020

eISSN : 2580-3042

pISSN : 1979-0694

\begin{tabular}{|c|c|c|}
\hline Wadas & 48.555 & 2.725 \\
\hline$\ldots$ & $\ldots$ & $\ldots$ \\
\hline Pakisjaya & 41.737 & 3.477 \\
\hline
\end{tabular}

c. Data Transformation

Pada tahap ini data berjenis numerik akan dilakukan standarisasi data ke skala 0-1 dengan menggunakan normalisasi min max. Tabel 4 merupakan hasil dari data transformation.

Tabel 4. Hasil Data Transformation

\begin{tabular}{|c|c|c|}
\hline Puskesmas & $\begin{array}{c}\text { Jumlah } \\
\text { Penduduk }\end{array}$ & $\begin{array}{c}\text { Maag } \\
\text { Tahun 2017- } \\
\mathbf{2 0 1 9}\end{array}$ \\
\hline Pangkalan & 0,324 & 0,023 \\
\hline Loji & 0,358 & 0,019 \\
\hline Ciampel & 0,340 & 0,008 \\
\hline Telukjambe & 0,531 & 0,023 \\
\hline Wadas & 0,428 & 0,023 \\
\hline$\ldots$ & $\ldots$ & $\ldots$ \\
\hline Pakisjaya & 0,368 & 0,030 \\
\hline
\end{tabular}

\section{d. Data mining}

Pada tahap data mining, algoritma yang digunakan yaitu algoritma $K$-Medoids dengan pengukuran jarak yaitu Euclidean Distance. Untuk pemilihan jumlah cluster yang optimal menggunakan Elbow Method. Grafik dari Elbow Method dapat dilihat pada Gambar

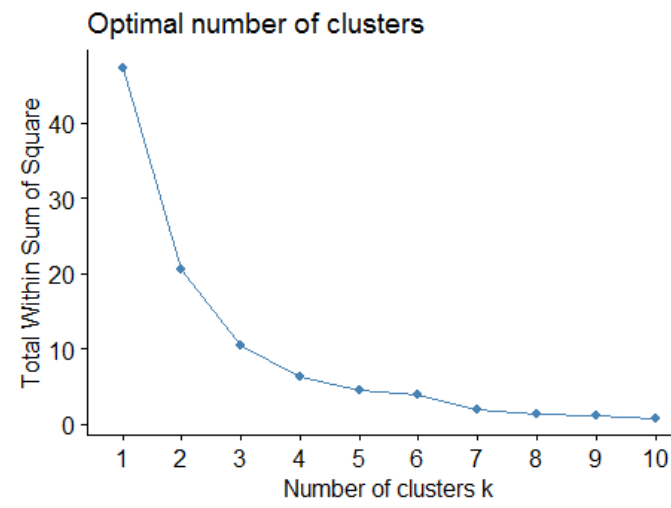

Gambar 3. Grafik Elbow Method

Dari hasil Elbow Method dapat diketahui bahwa nilai jumlah cluster optimal pada dataset penyakit maag Kabupaten Karawang tahun 20172019 yaitu 2 cluster. Setelah didapatkan jumlah cluster yang optimal selanjutnya yaitu proses

clustering dengan menggunakan pengukuran algoritma K-Medoids.

Pada dataset penyakit maag Kabupaten Karawang tahun 2017-2019 cluster yang dihasilkan yaitu 2 cluster yaitu cluster 1 dan cluster 2. Berikut merupakan plot dari dataset penyakit maag Kabupaten Karawang tahun 20172019.

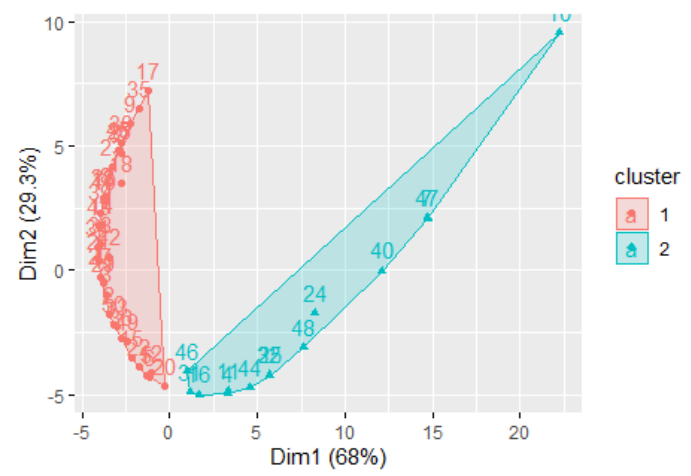

Gambar 4. Plot Cluster Penyakit Maag di Kabupaten Karawang

Adapun hasil cluster dari dataset penyakit maag Kabupaten Karawang tahun 2017-2019 dapat dilihat pada Tabel 4.

Tabel 5. Anggota Cluster

\begin{tabular}{|c|c|c|c|}
\hline \multicolumn{2}{|c|}{ Cluster 1} & \multicolumn{2}{|c|}{ Cluster 2} \\
\hline $\begin{array}{l}\text { Pangkalan, } \\
\text { Ciampel, } \\
\text { Wanakerta, } \\
\text { Anggadita, } \\
\text { Jomin, } \\
\text { Tirtamulya, } \\
\text { Cicinde, } \\
\text { Sukatani, } \\
\text { Bayurlor, } \\
\text { Tanjung } \\
\text { Tunggakjati, } \\
\text { Karawang } \\
\text { Majalaya, R } \\
\text { Balongsari, } \\
\text { Lemah } \\
\text { Kutawaluya, } \\
\text { Kalangsari, } \\
\text { Medangasem, } \\
\text { Sungaibuntu, } \\
\text { Kertamukti, P }\end{array}$ & $\begin{array}{r}\text { Loji, } \\
\text { Wadas, } \\
\text { Curug, } \\
\text { Kotabaru, } \\
\text { Cikutra, } \\
\text { Pacing, } \\
\text { Gempol, } \\
\text { asirukem, } \\
\text { Karawang, } \\
\text { pura, } \\
\text { Nagasari, } \\
\text { Kulon, } \\
\text { awamerta, } \\
\text { Tempuran, } \\
\text { duhur, } \\
\text { Kutamukti, } \\
\text { Jayakerta, }\end{array}$ & $\begin{array}{l}\text { Telukjambe, } \\
\text { Cikampek, P } \\
\text { Jatisari, Cilan } \\
\text { Lemahabang, } \\
\text { Telagasari, P } \\
\text { Adiarsa, Pede } \\
\text { Rengasdengk } \\
\text { Cibuaya, Bat } \\
\text { Tirtajaya }\end{array}$ & $\begin{array}{l}\text { lari, } \\
\text { rwasari, } \\
\text { aya, } \\
\text { lwad, } \\
\text { jk, } \\
\text { jaya, }\end{array}$ \\
\hline Jumlah & 35 & Jumlah & 15 \\
\hline Karakteristik & $\begin{array}{l}3.5- \\
300\end{array}$ & Karakteristik & $\begin{array}{l}7- \\
1058\end{array}$ \\
\hline
\end{tabular}


IN F ORMA TIK

Jurnal Informatika, Manajemen dan Komputer, Vol. 12 No. 2, Desember 2020

eISSN : 2580-3042

pISSN : 1979-0694

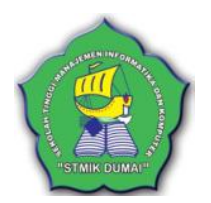

\begin{tabular}{|l|l|l|l|}
\hline Kategori & Rendah & Kategori & Tinggi \\
\hline
\end{tabular}

Pada Tabel 4 dapat diketahui terdapat 2 cluster pada dataset Penyakit Maag Kabupaten Karawang Tahun 20172019, yaitu cluster 1 memiliki jumlah 35 daerah, dengan tingkatan cluster daerah yang memiliki kasus penyakit maag Rendah di Kabupaten Karawang. Pada cluster 2 memiliki jumlah 15 daerah, dengan tingkatan cluster yang memiliki daerah penyakit maag Tinggi di Kabupaten Karawang.

e. Knowledge Interpretation/Evaluation

Setelah dilakukannya analisis pada cluster dengan menggunakan algoritma $K$-Medoids tahap selanjutnya dilakukan evaluasi terhadap model yang telah dibuat dengan menggunakan Silouette Coefficient yang bertujuan untuk mengetahui kualitas dari suatu objek pada suatu cluster. Dalam melakukan pengukuran pada kualitas cluster dengan menggunakan pengujian yang berpengaruh pada jumlah nilai cluster. Berikut merupakan hasil dari uji cluster.

Tabel 6. Nilai Silhouette Coefficient

\begin{tabular}{|c|c|}
\hline Nilai k & Silhouette Coefficient \\
\hline 2 & $\mathbf{0 , 5 5 6 1}$ \\
\hline 3 & 0,5237 \\
\hline 4 & 0,5086 \\
\hline 5 & 0,4844 \\
\hline 6 & 0,4671 \\
\hline 7 & 0,4726 \\
\hline 8 & 0,4695 \\
\hline
\end{tabular}

Tabel 5 menunjukkan hasil dari pengujian pada kualitas cluster pada dataset Penyakit Maag Kabupaten Karawang Tahun 2017-2019 dengan data uji 50 data, pengujian kualitas cluster yang di uji yaitu nilai $\mathrm{k}=2$ sampai $\mathrm{k}=8$. Kualitas cluster paling baik diperoleh pada cluster 2 dengan nilai Silhouette Coefficient sebesar 0,5561.

Berdasarkan hasil tersebut dapat disimpulkan bahwa cluster 2 merupakan cluster yang kualitasnya baik karena mendekati angka 1 (Medium Sturucture) berdasarkan Tabel 1 nilai Silhouette Coefficient struktur pengelompokan dinyatakan baik (Medium Sturucture).

\section{KESIMPULAN}

Pada penelitian ini telah diimplementasikan metode clustering menggunakan algoritma KMedodids dengan metodologi Knowledge Discovery in Database (KDD) untuk pengelompokan daerah penyakit maag di
Kabupaten Karawang pada tahun 2017-2019 menghasilkan 2 cluster yaitu cluster1 dan cluster2. Dimana Cluster 1 memiliki 35 daerah dikategorikan sebagai daerah yang memiliki kasus penyakit maag dalam tingkatan rendah daan pada cluster 2 memiliki 15 daerah, dan dikategorikan sebagai daerah yang memiliki kasus penyakit maag dalam tingkatan tinggi di Kabupaten Karawang.

Hasil clustering dievaluasi menggunakan Silhouette Coefficient untuk mengetahui kualitas dari sebuah cluster menghasilkan nilai Silhouette Coefficient 0,5561, hal tersebut menunjukan bahwa jumlah cluster 2 merupakan cluster yang memiliki kualitas yang baik karena mendekati angka 1. Hal tersebut dalam analisis pengelompokan data daerah yang memiliki kasus penyakit maag di Kabupaten Karawang lebih baik menggunakan 2 cluster sehingga data yang dihasilkan dari penerapan algoritmat $K$-Medoids akan mendekati ketepatan dalam pengelompokan daerah yang memiliki kasus penyakit maag di Kabupaten Karawang.

\section{REFERENSI}

Hardiyanti, F., Tambunan, H. S., \& Saragih, I. S. (2019). Penerapan Metode K-Medoids Clustering Pada Penanganan Kasus Diare Di Indonesia. KOMIK (Konferensi Nasional Teknologi Informasi Dan Komputer), 3(1), 598-603. https://doi.org/10.30865/komik.v3i1.1666

Kamila, I., Khairunnisa, U., \& Mustakim, M. (2019). Perbandingan Algoritma K-Means dan K-Medoids untuk Pengelompokan Data Transaksi Bongkar Muat di Provinsi Riau. Jurnal Ilmiah Rekayasa Dan Manajemen Sistem Informasi, 5(1), 119125.

Listiyanti, D., Syahbana, Y. A., \& Henim, S. R. (2016). Perancangan dan Implementasi Aplikasi Android Penentu Salient Area pada Video dengan Algoritma K-Medoids. 2(1), 96-101.

Marlina, D., Fernando, A., \& Ramadhan, A. (2018). Implementasi Algoritma KMedoids dan K-Means untuk Pengelompokkan Wilayah Sebaran Cacat pada Anak. Jurnal CoreIT: Jurnal Hasil Penelitian Ilmu Komputer Dan Teknologi Informasi, 4(2), 64-71.

Merliana, N. P. E., \& Santoso, A. J. (2015). Analisa Penentuan Jumlah Cluster Terbaik pada Metode K-Means Clustering. Prosiding Seminar Nasioanl Multi Disiplin 
I N F O R M A T I K A

Jurnal Informatika, Manajemen dan Komputer, Vol. 12 No. 2, Desember 2020

eISSN : 2580-3042

pISSN : 1979-0694

Ilmu, 978-979.

Novitasary, A., \& Ismail, C. S. (2017). Faktor

Determinan Gastritis Klinis pada

Mahasiswa di Fakultas Kesehatan

Masyarakat Universitas Halu Oleo Tahun

2016. Jurnal Ilmiah Mahasiswa Kesehatan Masyarakat Unsyiah, 2(6), 1-11.

Rahmayani, M. T. I. (2018). Analisis Clustering Tingkat Keparahan Penyakit Pasien Menggunakan Algoritma K-Means (Studi Kasus di Puskesmas Bandar Seikijang). Jurnal Inovasi Teknik Informatika, 1(2), 40-44.

Riyanto, B. (2019). Penerapan Algoritma KMedoids Clustering Untuk Pengelompokkan Penyebaran Diare Di Kota Medan (Studi Kasus: Kantor Dinas Kesehatan Kota Medan). KOMIK (Konferensi Nasional Teknologi Informasi Dan Komputer), 3(1), 562-568.

Rizby, L. P. (2018). Clustering pasien kanker berdasarkan struktur protein dalam tubuh menggunakan metode K-Medoids. Jurnal Pengembangan Teknologi Informasi Dan Ilmu Komputer (J-PTIIK), 6(1), 25-32.

Rofiqi, A. Y. (2017). Clustering Berita Olahraga Berbahasa Indonesia Menggunakan Metode K-Medoid Bersyarat. Jurnal SimanteC, 6(1), 25-32.

Savitri, A. D., Bachtiar, F. A., \& Setiawan, N. Y. (2009). Segmentasi Pelanggan Menggunakan Metode K-Means Clustering Berdasarkan Model RFM Pada Klinik Kecantikan (Studi Kasus: Belle Crown Malang). Jurnal Pengembangan Teknologi Informasi Dan Ilmu Komputer E-ISSN, 2548, 964X.

Statistik, B. P. (2019). Kabupaten Karawang dalam Angka 2019. Karawang: Badan Pusat Statistik Kabupaten Karawang.

Tussakinah, W., Masrul, M., \& Burhan, I. R. (2018). Hubungan Pola Makan dan Tingkat Stres terhadap Kekambuhan Gastritis di Wilayah Kerja Puskesmas Tarok Kota Payakumbuh Tahun 2017. Jurnal Kesehatan Andalas, 7(2), 217-225.

Wardhani, A. K., \& Khrisna, A. (2016). Implementasi Algoritma K-Means untuk Pengelompokkan Penyakit Pasien pada Puskesmas Kajen Pekalongan. Jurnal Transformatika, 14(1), 30-37.

Wira, B., Budianto, A. E., \& Wiguna, A. S. (2019). Implementasi Metode K-Medoids Clustering untuk Mengetahui Pola Pemilihan Program Studi. Jurnal Terapan 